\title{
Consideration on Size Limit of Droplets in Metal Jet Nozzle
}

\author{
Hiroshi NAKAMURA and Katsumi YAMAGUCHI*2 \\ *2 Mejep Co., Ltd., \\ 5-1-4 Takamoridai, Kasugai-shi, Aichi, 487-0032 Japan
}

\begin{abstract}
The authors have developed two types of metal jet nozzles, i.e., a molten metal type and an electric-discharge type. In the molten metal type, the molten metal droplets are jetted through a hole in the nozzle by the action of a piezo-electric actuator. In the first half of this paper, the jetting mechanisms of metal droplets and the minimum droplet sizes able to be jetted are discussed. Some considerations show that an ultra-small droplet can be jetted in the case of the molten metal having a concave meniscus to nozzle material. On the other hand, it becomes very difficult to jet smaller droplets in the case of molten metal having a convex meniscus. These discussions are confirmed by experiments under several combinations between molten metals and nozzle materials. In the electricdischarge type, molten metal droplets are jetted intermittently by blowing out the molten balls which are formed at the end of a metal wire by the electric discharge. The mechanisms of the droplet formation are discussed. On the bases of the discussion and the experimental results, the minimum and maximum droplet sizes are then estimated under practical conditions.
\end{abstract}

Key Words: Non-traditional Machining, Elactric Discharge Machining, Spraying, Metal Jet, Droplet, Nozzle, Printer

\section{1. まえがき}

著者らは過去メタルジェットプリンターの開発を手 がけてきた，その中でマイクロなドット状の溶融メ夕 ルを発射することを試み, 二つの形式のノズル，「溶融 式」と「放電式」ノズルを開発してきた(1)(2)。それ ぞれ低融点メタル, 高融点メタルの噴射に適したもの である、これまでは，このいずれのノズルに於いても メタルドットの発射には成功したが，どのようなメカ ニズムで, どのような条件下でドットが発射できるか, 特に噴射可能な最小ドット径についてはほとんど検討 されてはいなかった。

本研究は, 両ノズルにおいて, マイクロなメタルが 発射されるメカニズムを考察し, 主に噴射可能な最小 ドット径を検討して今後のノズル設計の指針とするこ とを目的としたものである.

\footnotetext{
* 原稿受付 2006 年 3 月 2 日.

*1 正員, メジェップ(株) (恶 487-0032 春日井市高森台 5-1-4).

E-mail : yama-katsu@ ha.bekkoame.ne.jp
}

\section{2. 溶融式ノズル}

\section{$2 \cdot 1$ 噴射メカニズムの考察}

\section{（1）噴射原理}

溶融式ノズルの構成を図 1 に示す。このノズルは比 較的融点の低い金属（目安として $430^{\circ} \mathrm{C}$ の亜鉛の融点 以下）である半田などの噴射を想定したものである.

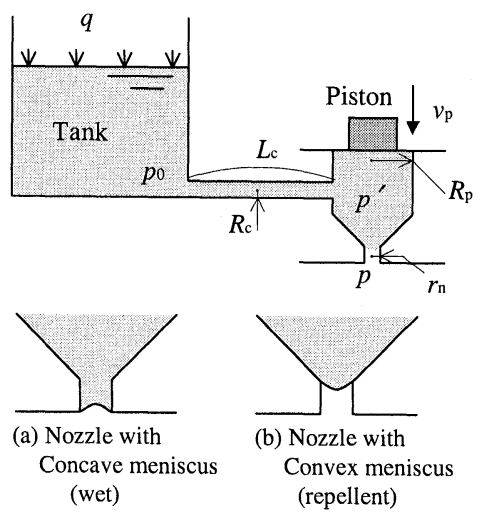

Fig.1 Schematic illustration of nozzle (Molten metal Type) 
タンクに溶融メタルを入れ, 絞り流路を介してノズル チャンバーに供給し，ノズルの背面から圧子を瞬間だ け押して, 噴射孔からドット状のメタルを発射させる 形式である．実際のノズルは，噴射孔出口付近はメタ ルの酸化を防ぐため窒素ガスで覆われている.

噴射方法はインクジェットプリンターと似ている が，インクのように液体とノズルが濡れ性を持つ場合 （メニスカスが凹状 : 図 $1 \mathrm{a}$ ）は, 流路や噴射孔を如何 ほどに小さくても, 液は表面張力の働きでそこを通過 できる，従って絞り流路を噴射孔と同程度に流れにく く設計するだけで, 圧子の押し行程によりノズル内に 高圧が発生し, 噴射孔から液体のドットが容易に噴射 できる. 圧子の引き行程においては, 液の表面張力の 働きにより噴射孔から気体が吸い込まれることなく, タンク内の液はノズルチャンバー内に引き込まれる.

しかし, 液がノズル材料と濡れ性が無く, はじかれ る場合（メニスカスが凸状：図 2b) はそうはいかない． 液は噴射孔の手前で停止する，絞り流路を噴射孔と同 程度に狭く設計すると, 液は絞り流路を通過できない ので, メタルの供給ができない，従って，このような ノズルは設計できない，かといって流路を広く設計す ると圧子の押し行程でノズルチャンバーに高圧が発生 しない.ノズル設計が大変難しいことになると予想さ れる.

このような場合の対策は絞り流路に逆止弁を設け ればよいが, マイクロなノズルであるので（0.1mm オ ーダー)そのようなことは無理がある. 仮にできても, 1 ドットの体積が小さい $\left(10^{-3} \mathrm{~mm}^{3}\right.$ オーダー) ので, 弁の開きが小さくなければならず，そこをはじく液を 通過させる弁の設計は不可能と言わざるをえない.

そこで, 以下に図 1 に示すノズルの噴射のメカニズ ムを裹付ける圧子の運動, 流路の設計および噴射圧の 検討を行ってみた.

\section{（2）圧子の運動}

圧子の運動は圧電素子を使って行ったが, 印加電圧 の波形を図 2 に示す. 素子の変位は電圧にほぼ比例し, 印加電圧 $100 \mathrm{~V}$ で, 変位は $6 \mu \mathrm{m}$ である.

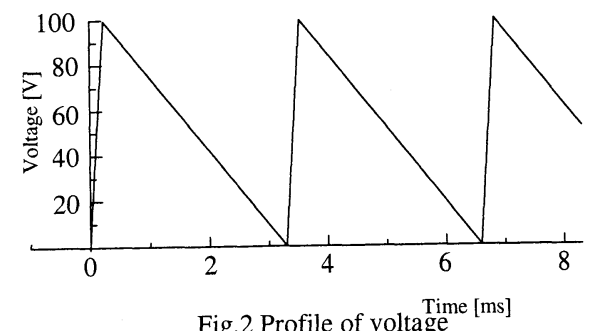

Fig. 2 Profile of voltage ${ }^{\text {Time }}[\mathrm{ms}]$
押し行程は，ゆっくりすぎては下記に検討する噴射 圧の条件を満をさないのでメタルを噴射出来ないし， 過度に早すぎては衝撃で噴射メタルが分離して噴霧状 態となる，適度な速さが必要である.

引き行程は, 噴射孔から気体を吸い込まずタンクか らメタルが補給されるためにはゆっくり引くのがよい が, あまりゆっくりでは噴射周波数が上げられないの で可能な限り速く引きたい.

実験では, 一例として半径 $0.1 \mathrm{~mm}$ のノズル噴射孔で, 半径 $1.5 \mathrm{~mm}$ の圧子を使って噴射したとき, $300 \mathrm{~Hz}$ ぐら いの周期の噴射が可能であった. その場合の両行程の 圧子の運動速度を求めると, 押し行程はおおよそ $70 \mathrm{~mm} / \mathrm{s}$, 引き行程はその $1 / 40$ の $1.8 \mathrm{~mm} / \mathrm{s}$ 程度の速さ であった。

\section{（3）噴射圧の検討}

一般に，マイクロなものの運動に於いては，“質量な どの慣性項はその効果が小さく, 粘性項や表面張力が 支配的になる. 従って, ノズル内に発生する圧力を流 路の粘性抵抗と表面張力の関係のみで単純化して検討 を試みることとする.

図 1 の各記号を用いて, 噴射孔が十分小さい場合は, 表面張力 $\gamma$, ノズル材との接触角 $\theta$ の液体を, 半径 $r_{n}$ の孔から噴射できる限界圧力 $p$ は表面張力と内圧のつ りあいの関係から以下のように表される.

$$
\begin{aligned}
& 2 \pi r_{n} \gamma \cos \theta=\pi r_{n}{ }^{2} p \\
& \therefore p=\frac{2 \gamma \cos \theta}{r_{n}}
\end{aligned}
$$

一方, タンク内絞り流路口にかかる静圧 $p_{0}$ の下で, 半径 $R_{p}$ の圧子の降下速度 $V_{p}$ によって長さ $L_{c}$ 半径 $R_{c}$ の絞り流路に流れる流体に流動抵抗が発生する. それ によってノズル内に発生する噴射圧力 $p^{\prime}$ は以下のよ うに求められる. 圧子の運動によって生じる流量 $Q$ は

$$
Q=v_{p} \cdot \pi R_{p}^{2}
$$

また, ハーゲン・ポアズイユの式により, 流量 $Q$ と 圧力差の関係は, 粘性係数を $\eta$ とすると

$$
Q=\frac{\pi R_{c}{ }^{4}\left(p^{\prime}-p_{0}\right)}{8 \eta L_{c}}
$$

であるので,

$$
p^{\prime}=\frac{8 \eta L_{c} V_{p} R_{p}{ }^{2}}{R_{c}{ }^{4}}+p_{0}
$$

となる.

式（1）（4）において， p'>pの条件を満たさない とメタルは発射できない. 
メタルの発射には $p^{\prime}$ が大きい程都合がよい，それ を実現できる条件は， $L_{c}, R_{p}, V_{p}$ が大きく, $R_{c}$ が小 さい方がよいことが分かる、マイクロノズルの設計で は $L_{c}, R_{p}$ の大きさは制限されるので，それなりの妥当 な寸法限界がある。 $V_{p}$ も先に述べたようにむやみに 大きくできない， $R_{c}$ は他のパラメータに抜きん出て 4 乗の効果があることと設計の自由度が大きいので, 噴 射を律する決定的なポイントであることが分かる。

$p_{0}=0$ の条件下で, 表 1 に示すような $L_{c}, R_{p}, V_{p}$ の值を使い $p^{\prime}$ を求めた. その結果を表の下段に示す. ここで $\mathrm{A}$ 欄は濡れ性のある場合, $\mathrm{B}$ 欄は濡れ性のない 場合を想定したもので, 絞り流路半径 $R_{c}$ の值は $\mathrm{A}$ の 場合はノズル噴射孔半径 $r_{n}$ 相当値とし, B の場合はメ タルがはじかれず通過できる最小孔径值相当としたも のである. $R_{c}$ 以外は全て実験に使った数值で, 両者同 じ值で比較した。 なお, 接触角 $\theta$ については溶融 $\mathrm{Sn}$ と SUS· $\mathrm{Cu}$ 表面についての実験から得られた值を用い，

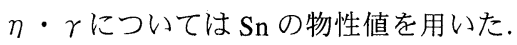

計算結果から,ノズル内に発生する圧力 $p^{\prime}$ は A の 場合 $25.6 \mathrm{kPa}$ で B の場合 $0.5 \mathrm{kPa}$ と格段の違いがある ことが分かる.

式（1）の表面張力による限界圧力 $p$ を噴射ノズル

Table.1 Numerical value

\begin{tabular}{|c|c|c|}
\hline & $\begin{array}{c}\text { A } \\
\text { Wet }\end{array}$ & $\begin{array}{c}\text { B } \\
\text { Repellent }\end{array}$ \\
\hline Radius of piston $R_{p}[\mathrm{~mm}]$ & \multicolumn{2}{|c|}{1.5} \\
\hline Radius of connecting tube $R[\mathrm{~mm}]$ & 0.15 & 0.4 \\
\hline Length of connecting tube $L[\mathrm{~mm}]$ & \multicolumn{2}{|c|}{5} \\
\hline Velocity of piston $v_{p}[\mathrm{~mm} / \mathrm{s}]$ & \multicolumn{2}{|c|}{72} \\
\hline Viscosity $\eta\left[10^{-3} \mathrm{~Pa}\right]$ & \multicolumn{2}{|c|}{2} \\
\hline Surface tension $\gamma\left[10^{-3} \mathrm{~N} / \mathrm{m}\right]$ & \multicolumn{2}{|c|}{526} \\
\hline Contact angle $\theta\left[{ }^{\circ}\right]$ & 40 & 140 \\
\hline Generated pressure $p$ ' $[\mathrm{kPa}]$ & $\mathbf{2 5 . 6}$ & $\mathbf{0 . 5}$ \\
\hline
\end{tabular}

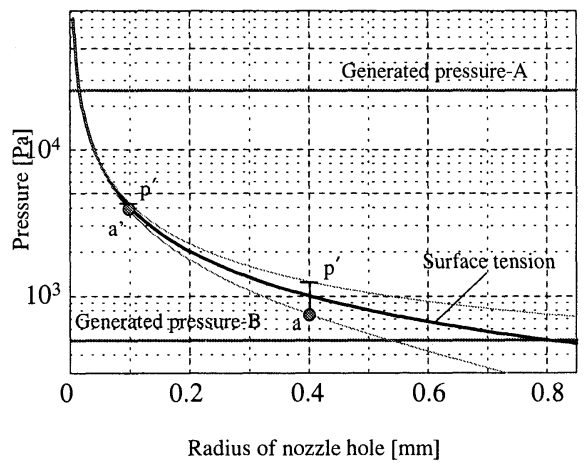

Fig.3 Relationship between hole radius and surface tension
孔径 $r$ に対して計算した結果を図 3 に示す，当然 $p$ は $r_{n}$ に逆比例関係の線で表される.この図に上記で求め た噴射圧力 $p^{\prime}$ を書き込むと, $p=p^{\prime}$ の交点は, A の場合は $r_{n}=0.016 \mathrm{~mm}$ となり, 非常に小さなメタルド ットの噴射ができる. B の場合は, $r_{n}=0.8 \mathrm{~mm}$ となっ て，それ以下の径のノズルではメタルの噴射ができな いことになる．濡れ性のある液体は濡れ性の無いもの に比べて如何に噴射し易いかが分かる．その原因は絞 り流路の設定に制限があることに起因することが分か る.

\section{（4）背圧の影霎}

上記では絞り流路口にかかる静圧 $p_{0}=0$ で計算した が，タンク内の液面ヘッドおよびその液面に背圧 $q$ を 与えることで，式（5）の $p_{0}$ を大きくすることで $p^{\prime}$ を大きくできる．但し，圧子が静止状態でノズルから 流れ出ないために， $p_{0}<p$ でなければならない。背圧 $q$ を加える方法はいわゆるディスペンサー方式と言わ れるものである．この方法を使えば，上記の式から濡 れ性のない場合でも次のようなことが予見できる.

(1) $q$ により $p_{0}$ が $p$ を少し下回る圧力を加えてお けば，いずれの $r_{n}$ に対しても噴射できることになる. B の場合, 図 3 に示すように, $p_{0}$ を $p$ 線直下の a 点に なるように背圧をかけておき，絞り流路での流動抵抗 によって生じる圧力を加えることで噴射できることに なる。

(2) 噴射孔が小さい場合(例えば $0.1 \mathrm{~mm}$ )には，高い 背圧で， $p_{0}$ を $\mathrm{a}$ '点にする必要であるにも拘らずノズ ル内に発生する圧力は変わらないので, 微妙な圧力の セティングをしなければならない，従って，噴射は相 対的に難しくなる。

(3) このように背圧を高くすれば，絞り流路を小さ くしてもメタルが通過できるので，ノズルへの補給が できる．絞り流路を小さくすると噴射圧は高くなるの で，噴射できる可能性は高くできる，しかし，絞り流 露の流動抵抗が大きくなるので，圧子の引き行程をゆ っくり引かないと，ノズル孔から気体を吸い込んでし まう。これは噴射周波数が上げられなくなることにな って, 不都合となる.

\section{（5）噴射限界の考察}

上記の考察から，噴射できる粒径は，濡れ性のある ノズルの場合には，噴射孔径を小さくし，それに応じ て絞り流路を小さくすれば，原理的には限りなく小さ なドット粒子が噴射できることになる.

濡れ性のないノズルでは, 式（5）から, ノズル孔 径に応じて背圧 $p_{0}$ を上げ， $R_{c}$ をそれに応じて小さく すれば圧力は 4 乗の効果となって噴射圧を上げること 
はできる，しかし，圧子の引き行程におけるメタルの 流入抵抗も同じように増えるので，ノズルの孔から気 体を吸い込むこととなってしまい, 丁度その効果と裏 腹にその分だけゆっくりと圧子を引かなくてはならな い.これは, 噴射周波数が落ちることになり, ノズル としての性能が維持できなくなる，言い換えれば，小 径粒子の噴射は難しくなる.

\section{$2 \cdot 2$ 実験方法およひ結果}

上記の考察を詳細に確認するためには, 系統的な実 験が必要であるが,一つのパラメー夕を変えるだけで, 実験は膨大な手間がかかり難しいので, 以下の事項に ついて考察を確かめた.

\section{（1）濡れ性のある場合}

噴射メタルは融点 $47^{\circ} \mathrm{C}$ の U アロイ（44.7Bi-5.3Cd22.6Pb-8.3Sn-19.1In）を用い, ノズル材料は濡れ性のあ る銅を使用した. 参考のため $183^{\circ} \mathrm{C} の \mathrm{~Pb}-\mathrm{Sn}$ 共晶半田 （38Pb-62Sn）についても実験した.いずれの場合も) ズルとタンクをメタルの融点より $10^{\circ} \mathrm{C}$ 程度高く加熱

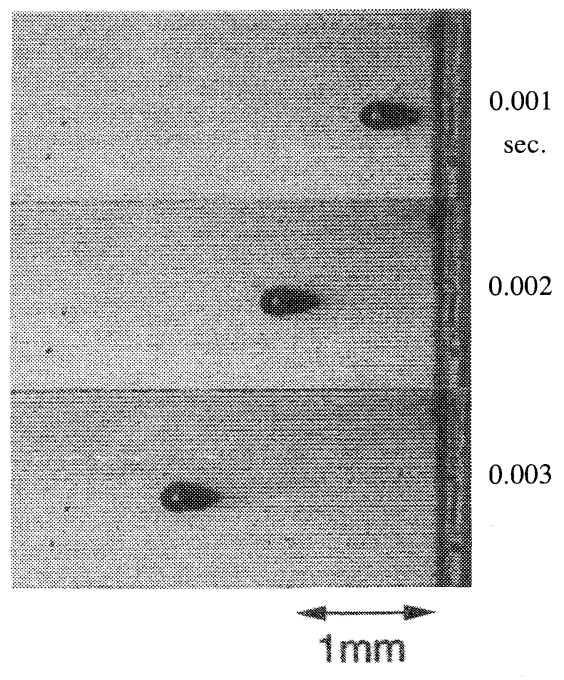

Fig.4 Serial photograph of metal shot

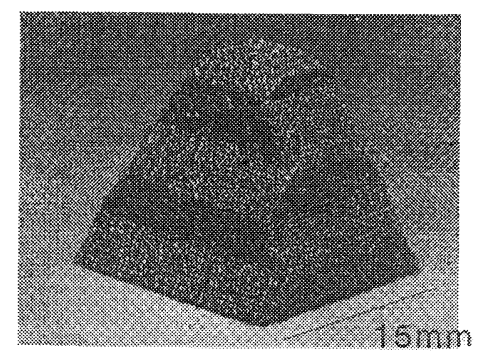

Fig.5 3-dimentional model made of $\mathrm{Pb}$-Sn solder
した状態に保った，各種寸法などの条件は，表 1 に示 されたものを使った。ノズル噴射半径 $r_{n}$ は $0.1 \mathrm{~mm}$ である.

いずれも噴射は容易にできた. そのときのUアロイ の噴射の様子を図 4 に示す. $\mathrm{Pb}-\mathrm{Sn}$ 共晶半田を噴射し, これを使って造形を試みたものを図 5 に示す．このと き, 絞り $R_{c}$ はノズル孔径とほぼ等しい穴径を目指した が, その大きさはあまり問題なく噴射できた.

濡れ性のある場合は極小粒径の発射が可能とした が, 別に $r_{n}=0.02 \mathrm{~mm}$ 以下の極小ノズルで Uアロイを 使って噴射を試みた．図6に示すように小径粒子の噴 射は可能であった.

当然のことながら，この方式には問題がある．それ は，ノズル材料である銅と溶融メタルとの間に濡れ性 があるが, 銅がメタルに少しずつ溶け込んで, 浸食さ れる.U ア アロイの場合で 2〜3 週間, 共晶はんだで 2 3 時間程度の実験でノズルが明らかな損耗を起こして しまった.

このように実験室では実験データは得られたが，こ のノズル材料では融点 $50^{\circ} \mathrm{C}$ 程度以上のメタルでは実 用的には使えないことが分る，濡れ性が高く，長期間 に亘って溶融ないしは合金反応しない材料の組合せが あればそれが望ましいが，通常の工業上の金属ではそ のようなノズル材料はなかなか得られない.

\section{（2）濡れ性の無い場合}

この実験に使用したメタルは先に述べたUアロイと 融点 $68^{\circ} \mathrm{C}$ のウッドメタル（50Bi-12.5Cd-25Pb-12.5Sn） である.ノズルはこれらと溶解・反応性がほとんど無 いステンレス鋼（SUS304）を使った. 当然濡れ性が無 い. 実験は条件 Bに示された設計条件で実験を行った. いずれも融点より $10^{\circ} \mathrm{C}$ 程高い温度で溶融した.

結果は, $p_{0}$ などの最適值を選んで噴射を試みたとこ ろ，いずれも噴射ができた．図 7 にウッドメタルの噴 射による文字プリント例を示す，しかしいずれの場合 も，噴射条件設定範囲が狭いものであった．また，半 径 $0.10 \mathrm{~mm}$ より小さい孔からは， $p_{0}, V_{p}$ など各種条

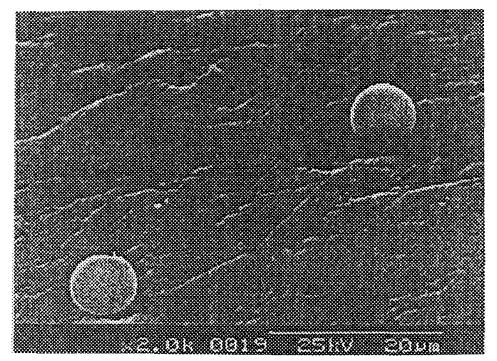

Fig.6 Drop of U-alloy 


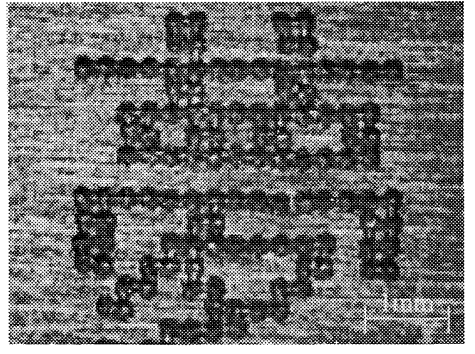

Fig.7 Metal printing by wood's metal

件を変えても噴射はしにくく不安定であった

以上, 不安定な原因は, 先に考察で明らかなように, 濡れ性のあるものでは，圧子の引き行程で，ノズル噴 射孔出口でメタルが表面張力の働きにより気体が吸い 込まれにくいのに対し, 濡れ性の無いものでは, メ夕 ルが噴射孔に入ることなく入り口で止まり，気体の吸 い込み防止は背圧のみによるため, 絞り流路を小さく できないことによるといえる，もし絞り流路を小さく すると, 負圧が生じて, 気体の吸い込みが発生して噴 射できなくなると考えられる。

以上から，このままでは，この方式のノズルでは耐 久性は得られるものの, 信頼性は低く, 実験室はとも かく実用的な使用には難があると判断できる.

著者らは, その後, この考察に基づき，噴射圧を増 強できる極めてユニークな噴射方式を創案し，濡れ性 の無い場合でも安定した噴射に成功した． (Electric discharge Type)
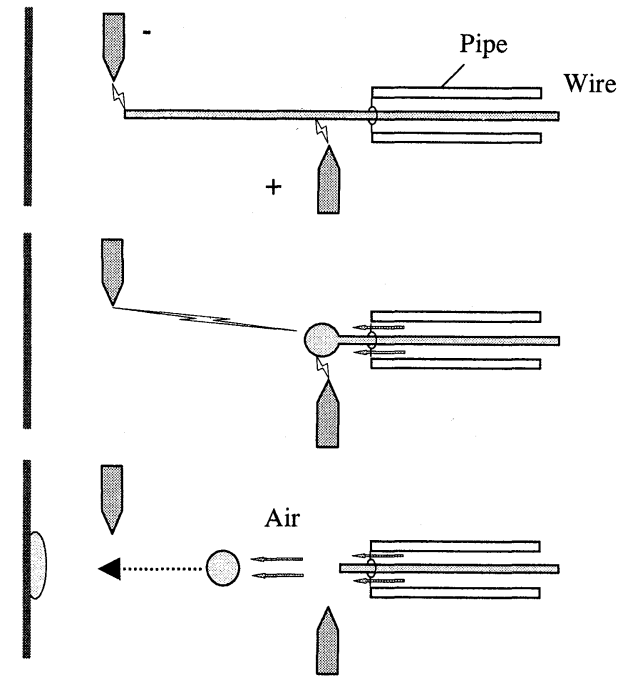

Fig.8 Schematic illustration of nozzle

\section{3. 放電式ノズル \\ $3 \cdot 1$ 噴射メカニズムの考察 \\ （1）噴射原理}

本方式のメタルの噴射原理を図 8 に示す．メタルの 細線を細いパイプに通して突出させて，側方に置かれ た電極から細線を介して放電させることで, 線端にメ タルの溶融球をつくる. 直後にパイプの中から気体パ ルスジェットで溶融球を吹き飛ばすものである.

\section{（2）喷射限界の考察}

気体のジェットによって，溶融メタルを噴射できる 最小限界を検討する.

放電で溶融されたメタルは表面張力により球を形成 する. 図 9 にそのモデルを示す，噴射はこのような溶 融球を気流で線軸方向に吹き飛ばすのである，吹き飛 ぶ条件は付け根の表面張力以上に溶融球に気流の抵抗 が生じなければならない。そその抵抗力は球の形状によ って決まり, 球の形状は気流から受ける摩擦力, 流体 力, 表面張力のバランスで決まる.この問題を流体力 学的に解くのは極めて難しいので，以下に近似の見積 もりを行う.

半径 $r_{w}$ の細線が長さ $L_{w}$ だけ融けた場合の体積と, 形成される溶融球の体積の関係は

$$
\pi r_{w}{ }^{2} L_{w}=\frac{4}{3} \pi R_{b}^{3}
$$

であることから, 半径 $R_{b}$ は

$$
R_{b}=\left(\frac{3}{4} r_{w}{ }^{2} L_{w}\right)^{1 / 3}
$$
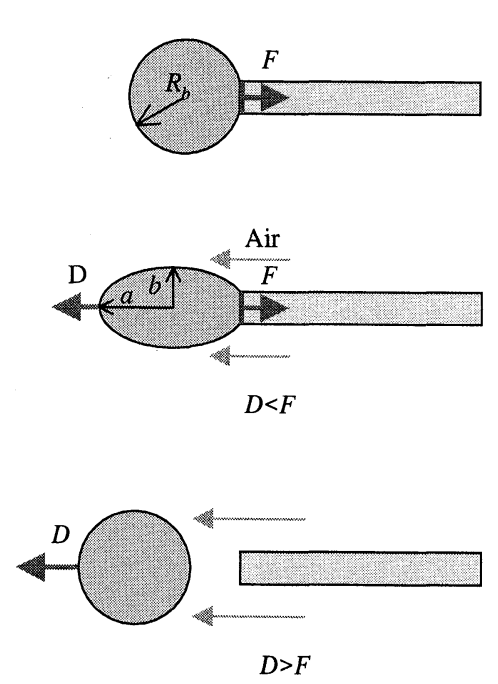

Fig.9 Schematic illustration of release of droplet 
半径 $R_{b}$ の溶融球が気流から受ける抵抗によって, 流 れに形状が馴染んで, 近似的に長半径 $a$, 短半径 $b$ の 棈円形状に変形させられると仮定すると

$$
R_{b}=\left(a b^{2}\right)^{1 / 3}
$$

の関係が得られる.

この棈円体の長軸方向に働く空気抵抗 $D$ は軸の面積 $\pi r_{w}{ }^{2}$ に空気があたらないことを考慮して, 気流の流 速を $V_{a}$ とすれば

$$
D=\frac{1}{2} C_{D} \rho v_{a}^{2} \cdot \pi\left(b^{2}-r_{b}{ }^{2}\right)
$$

で表される．ここで, $C_{D}$ は抗力係数で, 係数は一般に レイノルズ数や形状によってわずかに変化するが, 実 験におけるレイノルズ数は $10^{3} \sim 10^{4}$ 程度であり形状に 関係なくほぼ $C_{D}=0.4$ である(3).

半径 $r_{w}=0.025 \mathrm{~mm}$ の金属線について, 流速 $V_{a}=$ $300 \mathrm{~m} / \mathrm{s}$ に扮ける $a / b=c$ を変化させていった場合の空 力抵抗を計算してみると, 図 10 のように表される.

一方, 溶融体が金属線から表面張力 $\gamma$ の働きによる 付着力 $F$ は

$$
F=2 \pi r_{b} \cdot \gamma
$$

この值を図 10 に書き込むと,水平な実線で表される. 式（3）>式（4）で決まる点が, 飛しょうする最小 限界を与え, この值以上であれば, 溶融球は飛しょう することになる.

一方, 最大溶融長さ $L_{\mathrm{w}}$ は安定して放電が持続する最 大放電長さで決まる.この值は実験から定められる.

\section{$3 \cdot 2$ 実験方法および結果}

実験に使ったノズルの概要を図 11 に示す.表 2 に示 す条件で噴射を試みた。使用した金属線は金, ジエッ トは音速に近い空気である.

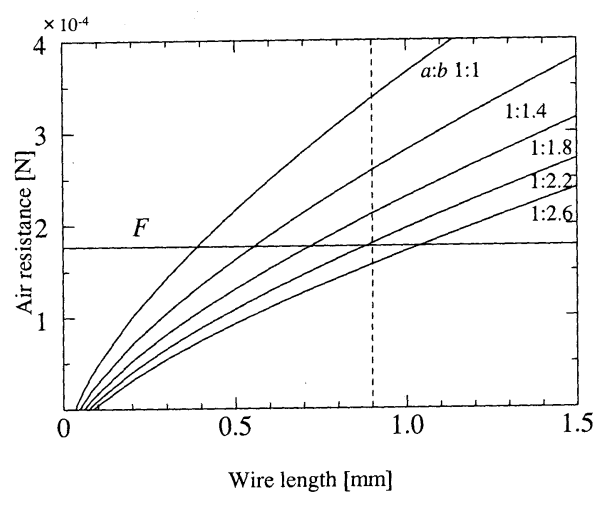

Fig.10 Criterion of shooting (Au $r=0.025 \mathrm{~mm} \quad v=300 \mathrm{~m} / \mathrm{s}$ )
放電により金線の先を溶融させそのまま, 凝固させ たものを図 12 に示す.表面張力によりほぼ真球が形成 される.これを溶融状態で空気ジェットにより銅板上 に噴射したものを図 13 に示す. 高速で衝突し, 瞬時に 凝固したため中央がへこんだ底付きのドーナッツ状を している.

このような噴射実験に於いて噴射可能な溶融長さ

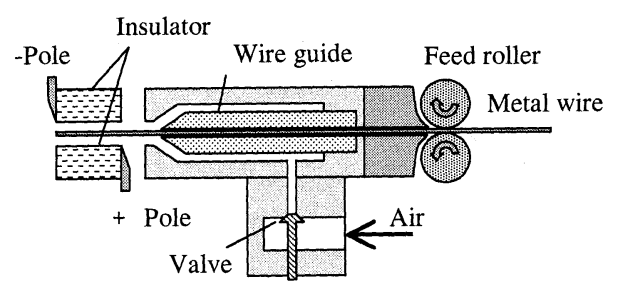

Fig.11 Detail of nozzle

Table 2 Experimental condition

\begin{tabular}{|c|c|}
\hline Wire & $\mathrm{Au}$ \\
\hline Wire radius $[\mathrm{mm}]$ & 0.025 \\
\hline Jet & Air \\
\hline Jet velocity $[\mathrm{m} / \mathrm{s}]$ & 300 \\
\hline Discharge current $[\mathrm{mA}]$ & 70 \\
\hline Discharge time $[\mathrm{ms}]$ & 7 \\
\hline
\end{tabular}

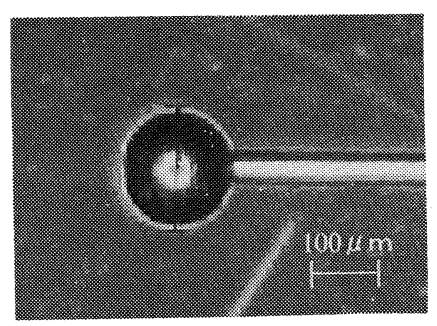

Fig.12 Molten metal ball (Au wire, $r_{w}=0.025 \mathrm{~mm}$ )

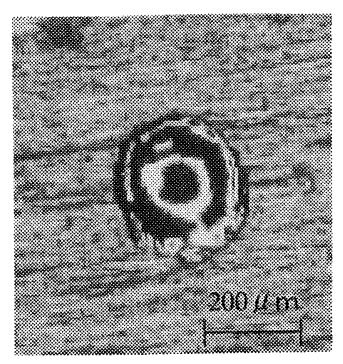

Fig.13 Drop of gold 
$L_{w}$ と粒径を測定した．その結果を図 14 に示す.

溶融長さ $L_{w}$ の設定を大きくした場合は, 放電により 金属線の先端が溶融して放電距離がしだいに伸びてゆ き, 放電が途中で断絶してしまって, 所定の溶融がで きなくなる.この放電長は電源の特性, 気体の状態, 電極材料などの影響を受けるが，それらが定められる と, それに応じた放電限界の長さ $L_{w}$ が決まる. 本実験 では図示のように最大溶融長さ $L_{w}=7 \mathrm{~mm}$ であった. この値は線径によってはあまり変わらない值である.

一方, 設定溶融長さが小さい場合, 溶融球が小さ過 ぎて, 空気で吹き飛ばすことができない，その限界は 図に示されているように $L_{w}=0.9 \mathrm{~mm}$ であった.

以上の結果, 溶融長さ $0.9 \sim 7 \mathrm{~mm}$, 即ち粒径 150〜 $300 \mu \mathrm{m}$ のドット粒子の噴射ができた.

この飛しょうさせることができる最小粒子条件を 図 10 に示した予測值と対応させると, 溶融球が飛しょ うする際に変形する形状を示す $a / b$ の值は 2.25 程度と 推測できる.

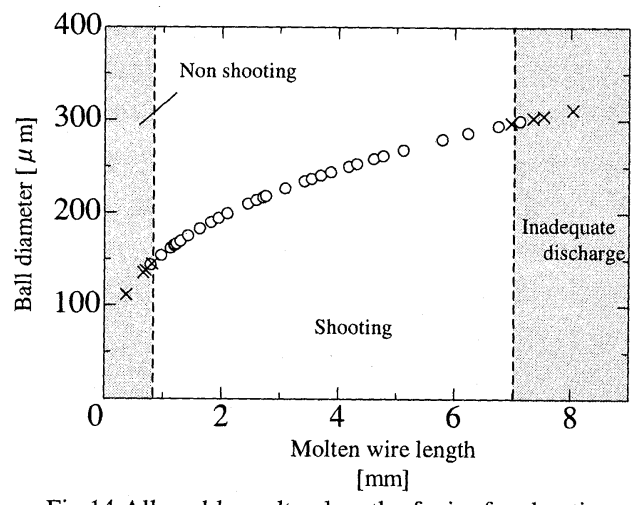

Fig.14 Allowable molten length of wire for shooting (Au $r_{w}=0.025 \mathrm{~mm}$ )

\section{3 噴射限界粒子径}

金属線を細くすればするだけ小径の粒子が噴射で きる，その限界を，ここで推測された楕円形状で吹き 飛ばされると仮定して飛しょうさせられる最小粒径を 予測してみる. また同時に, 限界放電長から予測され る発射可能な最大粒径も求められる，その計算による 予測結果を表 3 に示す.

使用する線径に応じて噴射可能な粒経が変わる. 仮 に使用できる線半径が $0.005 \mathrm{~mm}$ とすれば最小粒経は $61 \mu \mathrm{m}$ となる. 市販の最小線半径は金線で $0.015 \mathrm{~mm}$ で あることから，技術的に入手可能な線半径は $0.005 \mathrm{~mm}$ が限界と考えられる. その場合, 本方式で発射可能な
限界最小粒径は約 $60 \mu \mathrm{m}$ と予測できる.

なお, 溶融球の飛しょう状況を実際に観察したい之 考えたが，この現象が起こるのは $10^{-6} \mathrm{~s}$ 時間内の現象 であり, 放電状況の下でかつ顕微鏡で観察しなければ ならないことから, 観察はとてもできなかった.

Table 3 Allowable condition for shooting

\begin{tabular}{|c|c|c|c|}
\hline $\begin{array}{c}\text { Wire radius } \\
{[\mathrm{mm}]}\end{array}$ & $\begin{array}{c}\text { Minimum } \\
\text { wire length } \\
{[\mathrm{mm}]}\end{array}$ & $\begin{array}{c}\text { Minimum } \\
\text { diameter } \\
{[\mu \mathrm{m}]}\end{array}$ & $\begin{array}{c}\text { Maximum } \\
\text { diameter } \\
{[\mu \mathrm{m}]}\end{array}$ \\
\hline$\phi 0.01$ & 1.51 & 61 & 102 \\
\hline$\phi 0.02$ & 1.17 & 89 & 161 \\
\hline$\phi 0.04$ & 0.95 & 132 & 256 \\
\hline$\phi 0.05$ & 0.91 & 151 & 297 \\
\hline$\phi 0.06$ & 0.87 & 167 & 336 \\
\hline$\phi 0.08$ & 0.83 & 200 & 407 \\
\hline$\phi 0.10$ & 0.81 & 230 & 472 \\
\hline
\end{tabular}

\section{4. 結論}

メタルジェットの噴射現象の考察と実験から，噴射 可能粒径について, 次のことが結論づけられた.

（1）溶融式ノズルでは，濡れ性のあるノズル材料が 使えれば，原理的には極めて小さいメタルも噴射でき る、濡れ性の無いノズルを使わなければならないとき は, 背圧を使い微妙な設計条件を満たさなければない. また，小径の粒子の噴射は極めて難しくなる.

（2）放電式ノズルでは，メタルを飛ばすために必要 な金属線の最小溶融長を予測する簡便手法を示し，そ れに基づき噴射可能な最小粒径を予測した。

\section{0. 参考文献}

(1) Yamaguchi, K., Sakai, K. et al., Generation of Three-dimensional Structure Using Metal Jet, Journal of the Japan Society for Precision Engineering, Vol.64, No.10 (1998), pp. 1497-1501.

(2) Yamaguchi, K., Nakamura, H., Development of Electric-Discharge Type Metal Jet Nozzle for Printer. Transactions of the Japan Society of Mechanical Engineers, Series C, Vol.072, No.720 (2006), pp.2656-2661.

( 3 ) The Japan Society of Mechanical Engineers ed., JSME Mechanical Engineers'Handbook, (1996), A5-p98, The Japan Society of Mechanical Engineers. 